\title{
THE DEVELOPMENT OF MINAPOLITAN AREA BASED ON PARTICIPATORY PLANNING IN INCREASING FISHERMEN COMMUNITY WELFARE: A STUDY IN MINAPOLITAN AREA OF SEI IJUM RAYA VILLAGE, EAST KOTAWARINGIN REGENCY
}

\author{
Nurmarini Vita Maya*, Hakim Abdul, Rozikin Muhammad \\ Master's Program in Public Administration, Faculty of Administrative Science, \\ University of Brawijaya, Indonesia \\ *E-mail: vitamayareva@gmail.com
}

\begin{abstract}
One of the development priorities implemented by the government is economic development, as one of the backbones of the national economy, which is capture fishery sector. Sei ljum Raya village has a huge fishing potential supported by the natural and geographical condition of the area which is flowed by a Mentaya River. Broadly, Minapolitan area development planning in Sei ljum Raya village aims to improve the welfare of the community, especially fishermen. The problems' complexity raises the need for community involvement planning in the development of Minapolitan areas to support the utilization of potentially productive resources. Sei ljum Raya village with its various potentials may be considered as a unique village, in which coconut palm is a potential that can be utilized, but the community awareness on the importance of exploring the region potential is still very minimal. The findings of the field showed that there were acceleration and breakthrough efforts in marine and fishery development supported by economic policy as well as conducive social and political climate. In this case, cross-sectoral coordination and support, as well as other stakeholders, become one of the most important prerequisites.
\end{abstract}

\section{KEY WORDS}

Natural resources, income, fishermen communities, inhibiting factors, human resources, infrastructure.

One of the development priorities implemented by the government is economic development, especially populist-based economy. Indonesia with vast territorial water has a great potential as one of the national economy backbones, including the capture of fisheries sector. More specifically, East Kotawaringin Regency in general and Mentaya Hilir Selatan sub-district, in particular, has a great potential of capture fisheries, supported by its natural and geographical condition of the area which is flowed by the big river (Mentaya River). Along the river up to the estuary (Java sea), there are many fishermen's settlements that hereditary conduct capture fisheries activities. Sei ljum Raya village is a pre-eminent village of a center minapolitan area that has a superior performance in terms of seafood production, which is good in the fishery products processing. Broadly speaking, this plan aims to support government programs in the field of development and improvement of fishery products, especially capture fisheries, which is located in the selected area of Minapolitan fishery center, Sei ljum Village, South Mentaya Hilir District, East Kotawaringin Regency. Especially for fisheries, the abundant potential is expected to become the leading sector of the national economy.

Indonesia's Law No. 31 of 2004 on fisheries has an important role. Minapolitan concept is the basis of marine and fisheries sector development that aims to improve the welfare of fisheries communities with the purpose of reducing the gap that occurs in fishing communities. Revenue per capita is one indicator that can measure the level of community welfare.

Based on its PDRB per capita, East Kotawaringin's tends to increase every year. Regional economic growth is one of the most important elements in the community welfare, especially Sei ljum Raya Village. The great fishery potential provides benefits that can be 
generated. East Kotawaringin Regency Government issued the decree of Regent of East Kotawaringin No.188.45/ 326/ Huk-DKP/ 2015 which stipulates that the core location is located in Sei ljum Raya Village, South Mentaya Hilir District. To support the development of Minapolitan area, it should be supported by the community around the area so that the production process in the cultivation area (upstream), agro-industry (downstream) as well as in the distribution and marketing (supporting) can be realized well.

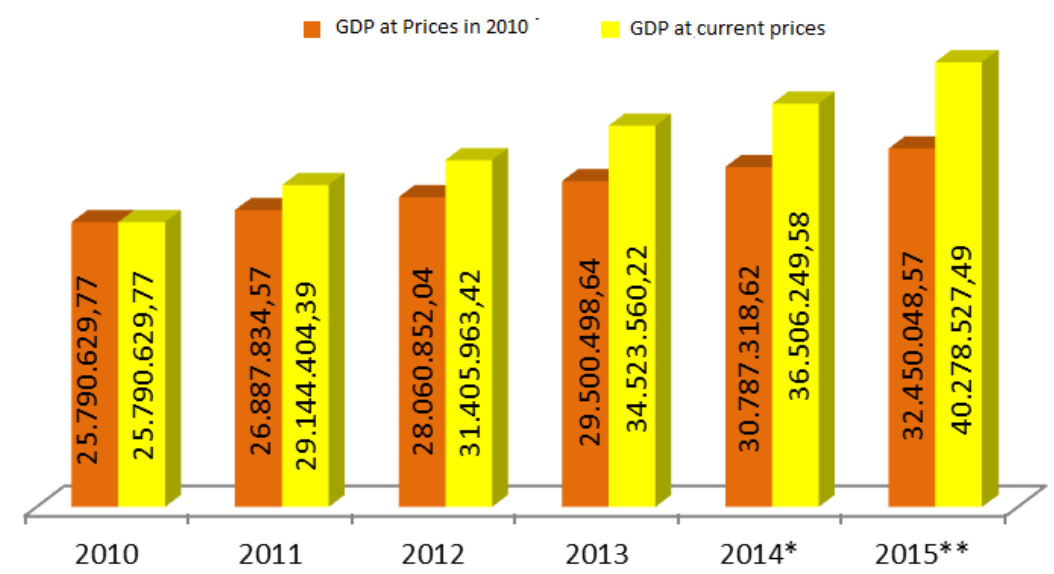

Figure 1 - PDRB Per Capita Growth of East Kotawaringin Regency in 2010-2015

The concept of development is in line with the general direction of national development and the policy direction of regional development and area development explained in RPJMN 2016-2021 with the aim to accelerate the development of maritime areas.

In this case, improving the welfare and independence of a community is not an easy thing. It requires a direction and a series of efforts, therefore participatory (involvement) of the community to create a synergy is needed to ensure effective, efficient, fair, environmentally and sustainable success. To do such sustainability, it requires the optimization of Sei ljum Raya village community. The spotlight of the Minapolitan area development planning is that the community has not been able to optimally support the government's program and the concern of local government in demanding the community's awareness so that the community involvement is needed. Participatory planning is an appropriate tool to optimize the community participation in planning.

\section{LITERATURE REVIEW}

Area Development Planning. Development is a planned effort conducted to obtain a better state in various aspects of life. Kartasasmita states that development is done because of the need of improving in order to develop social, political and economic institutions so that the development is succeeding quickly, in which planning can be mean as guidelines or just a map of what to do. Planning is divided into four criteria which are:

1. The Nature of planning goals. The planning classification is according to the nature of the objectives designed to be achieved. This classification is a "goal-oriented" classification or a functional one.

2. The scope of planning activities. This classification takes into account the scope of planning activities designed to be influenced. This approach produces a classification on the discipline or professional path.

3. The spatial level of planning activity. Planning can be done at any level from the individual to the world as a whole. So categories such as international planning can be distinguished.

4. The operational level of planning activity. The classification of planning according to the level of "operational" planning activities which is planning development in a nation-state. 
In planning the development of a developing regional area, there are several things, including:

1. Planning is the process defining the goals of a plan, creating a strategy to achieve the goal and developing a work activity plan in a planning.

2. Organizing is an activity process in constructing the organizational structure in accordance with the purpose and source as well as environment

3. Actuating is an action that trying to realize the planning and the goal properly.

4. Controlling is a process of observation, the determination of the standard to be realized, assessing the implementation performance, and if necessary taking corrective action, so that the implementation can run as closely as possible to achieve the goal.

Participatory Planning. The community role in the Law No. 32 of 2014 which is initially small is encouraged to participate in the government. The participation of a person or group of community members in an activity. Bornby (1974) defines participation as an action to "take part" which is activities or statements to take part of the activity for the purpose of obtaining benefits (Webster, 1976).

Related to that, Muluk (2007: 127) states that public participation is not only derived from the bottom, but there are also initiatives from the above in the form of government efforts to increase the participation. In this research, participatory planning is used as an indicator to see if the planning is done in accordance with what is expected. Yadav (UNAPDI, 1980) points out that there are four kinds of activities that show participation decision making, implementation of activities, monitoring, and evaluation, as well as participation in the utilization of development outcomes.

Conyers (1992: 154) argues that there are at least three important reasons why community participation is needed in development: first, community participation can be used as a tool to obtain information about the conditions, needs, and attitudes of the local communities to support the success of programs or projects to be implemented in the area. Second, the community will trust the project or the development program more if they feel involved in the preparation and planning process, as they will know more about the project and will have a sense of ownership of the project; and thirdly, it is an effort to encourage general participation in many countries, as it is perceived that it is a democratic right if society is involved in the development of their own community.

Participatory Planning in Community Development Perspective. Korten (1984), community development as a concept of social change must be recognized to always refer to or based on the paradigm of community-based development. It can simply be defined as development that refers to community needs, planned and implemented by the community by utilizing the resources potential (nature, human, institutional, socio-cultural values, etc.) as big as possible. Community development which aims to improve the community welfare or quality of either life, inward, material and spiritual.

Through the community ability's participation and their struggle to awaken and sustain collective growth, it becomes strong. But such participation means not only that community is involved in the implementation of the development or the community is only considered as an "object" but must be followed by the involvement of the development community, or the community is also considered as the main "subject" that must determine the course of development. The success of community development depends on the role of the government and its community, therefore empowerment is conducted as a process of community development. Prijono and Pranarka (1996: 15) state that it requires three phases which are of the initial stage, participatory stage, and emancipatory stage. Sumadyo (2001) in Mardikantoro formulates three main efforts in every community empowerment, which are called as Tri Bina including: Human Development, Effort Development, and Environmental Development. As an outline that the process of community empowerment can be done gradually until the end to improve the community's welfare. 


\section{METHODS OF RESEARCH}

This research is qualitative with descriptive type aims to obtain the description of the involvement of Sei ljum Raya Village community the in minapolitan area development in East Kotawaringin regency, focusing on:

1. The Identification of Minapolitan Area Development:

- Exploration of Sei ljum Raya village potential;

- Local government support in developing Minapolitan Area in Sei ljum Raya Village.

2. Sei ljum Raya village community involvement in the process of development planning of Minapolitan area through Participatory planning:

- The Stages of Minapolitan area development planning process;

- The forms and quality of community participation in the development of Minapolitan area in Sei ljum Raya Village;

- The actors involved in participatory planning process in the development of the minapolitan area;

- The Institutions that can be developed to become a forum for Sei ljum Raya Village community through community empowerment.

3. Supporting and inhibiting factors in the development of minapolitan areas based on participatory planning in improving the fishermen communities' welfare in Sei ljum Raya Village.

This research was conducted at the Regional Development Planning Board of East Kotawaringin Regency, Marine, and Fisheries Office of East Kotawaringin Regency, South Mentaya Subdistrict Office, Sei ljum Raya Village Office. The selection of this location also allows the researchers to obtain data or information exactly as needed. The data sources of this research consist of:

1. Informant;

2. Head of BAPPEDA of East Kotawaringin Regency;

3. Head of Marine and Fisheries Office of East Kotawaringin Regency;

4. Head of Program Development Sub-Section, Department of Marine Affairs and Fisheries of East Kotawaringin Regency;

5. Chairman of Dayak Customary Council of East Kotawaringin Regency; and

6. Planning target group, which consists of local communities in East Kotawaringin Regency; and Indigenous People of East Kotawaringin Regency;

7. Documents, in the form of general regional data related to the development of regional tourism minapolitan area in East Kotawaringin District, such as: The Profile of East Kotawaringin Regency, Strategic Plan of Marine and Fisheries Office, RPJMD 2016-2021 of East Kotawaringin Regency, including some other supporting data associated with this study.

The data collection in this research is done by:

1. Direct Interview, which is a technique or effort of collecting data or information directly related to the research object by conducting the question and answer with the informants determined using interview guides.

2. Observation, which is a technique of data collection conducted through direct observation in the field in order to obtain data to complement or improve the data obtained through interviews.

3. Documentation, is a data collection technique conducted by learning various reports, documents, archives, brochures, magazines, internet, newspapers and relevant data related to the issues raised in the research.

The instrument used in this research are:

1. Researcher herslef. This is in accordance with the research method used, which is qualitative research, in which data collection depends on the researcher themselves. Researcher as the main instrument (instrument guide) by using the senses to watch and observe objects or phenomena in this research.

2. The interview guide, which is a series of questions used as a guide or framework in conducting the interviews with respondents involved as a source of data in this study. 
3. Stationery and field notes. Stationary is the instrument to assist in recording important points in the field and the records are the result of the research heard, observed and considered in the framework of data collection and data reflection in qualitative research. The analysis of qualitative data is typically an interactive and active process. Meanwhile, to see the data validity, there are four criteria in conducting data validity test which is: credibility, transferability, dependability, and confirmability.

\section{DISCUSSION OF RESULTS}

Development center is an expanse of economy-scale fishery commodities in a mina ecosystem area, where the area is equipped with infrastructure as well as facilities needed such as institution, processing/ marketing, and other sectors that support the development of commodity center. Sei ljum Raya village has a stretch of fish commodity surrounded by deep coconut utilized by the fishermen community.

Identification of Minapolitan Area Development. Regional development is a plan to improve the use of various resources. An area as a whole is an economic unit in which there are various sources that interact with each other through the potential of the region that can be utilized as a regional capability in order to realize the community welfare. With the total population of 78 are fishery households (RTP) with fishery yield productivity of 8 tons/month ( $80 \%$ of shrimp and $20 \%$ rough fish). Capture fisheries (marine), $75 \%$ of fisheries production by 2015 is 11.8,000 tons, comes from 14 fishing villages in 3 coastal districts of Minapolitan area, $65 \%$ from Sei ljum village and hinterland village able to create functional relationship and marketing of capture fishery production. The regulation issued in the form of Decree of Regent of East Kotawaringin No.188.45/ Huk-DKP/ 2015 which specifies the support locations in 3 districts: Teluk Sampit Sub district, South Mentaya Hilir Sub district, and Hanaut Island. Two Teluk Bay sub-districts and Hanaut Island, and aquaculture fishery in Kota Besi Regency. Meanwhile, in Sei ljum Village, South Mentaya Hilir District is developed as Minapolitan.

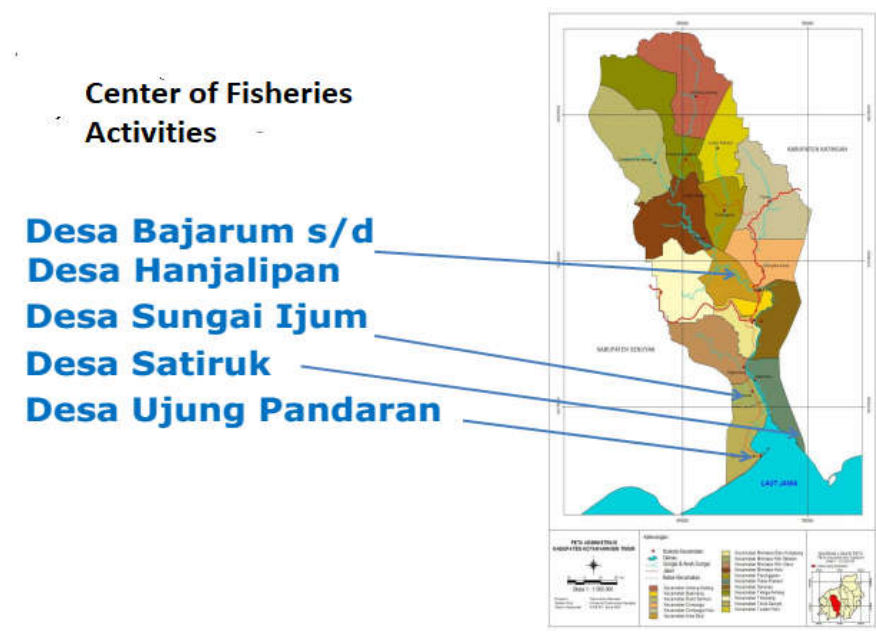

Figure 2 - Fishery Center Map

Since the establishment of Sei ljum Raya village becomes a minapolitan, most fishermen with coconut plantations are very enthusiastic to build fish ponds in the last 1-2 years. Around ( \pm 180 units) is integrated fish-deep coconut. However, the lack of public awareness of the potential exploration of the region still needs to be improved. With the potential identification by using LQ theory, the higher the number of community involvement in certain natural resources, the higher the contribution of these sources to the economic development, with the indication is seen in the Gross Regional Domestic Product (GRDP). The determination of the leading sector becomes very important as the basis of regional development planning, where the regions have the opportunity and authority to make a 
breakthrough in accordance with the potential of the region in order to accelerate the area development for the improvement of its community welfare.

Table 1 - LQ (Location Quotient) Calculation Result of East Kotawaringin Regency in 2013-2016

\begin{tabular}{|l|c|c|c|c|c|}
\hline \multicolumn{1}{|c|}{ Economy Sectors } & \multicolumn{3}{c|}{ Location Quotient } & Mean \\
\cline { 2 - 6 } & 2013 & 2014 & 2015 & 2016 & \\
\hline 1. Agriculture, Forestry and Fisheries & 2.21 & 8.64 & 6.08 & 8.55 & 6.00 \\
\hline 2. Mining and Excavation & 62.08 & -18.72 & -1.23 & 9.42 & 12.00 \\
\hline 3. Processing Industry & 3.82 & 13.53 & 9.28 & 8.94 & 8.00 \\
\hline 4. Electricity and Gas Excavation & 6.52 & 30.49 & 18.00 & 13.20 & 17.00 \\
\hline 5. Water Supply, Waste Management, Waste and Recycling & 3.10 & 2.56 & 4.71 & 5.41 & 3.00 \\
\hline 6. Construction & 4.77 & 11.93 & 8.19 & 5.06 & 7.00 \\
\hline 7. Great Retail Trade & 2.84 & 10.25 & 9.35 & 8.07 & 7.00 \\
\hline 8. Transportation and Warehousing & 15.62 & 0.35 & 9.29 & 12.41 & 9.00 \\
\hline 9. Accommodation and food-drink Suply & 7.79 & 11.57 & 10.45 & 6.74 & 9.00 \\
\hline 10. Information and Communication & 10.73 & 18.63 & 7.93 & 3.48 & 10.00 \\
\hline 11. Services & 9.30 & 8.96 & 4.62 & 3.01 & 6.00 \\
\hline
\end{tabular}

Source: Processed from KDA data of 2015.

The formula proposed by Bendavid-Val shows that the fishery sector in East Kotawaringin Regency is very potential. Seen from other commodities, deep coconut agricultural production has considerable potential, thus it allows an integration in terms of plantations, fisheries, and agriculture. Therefore, the integration of deep coconut-fish cultivation can be an alternative to support the development of the minapolitan area. Additionally, with the local government support through a relevant agency, the location of Minapolitan area is a huge opportunity for Sei ljum Raya Village. The synergy of policy implementation is needed in realizing the development of the minapolitan area with the utilization of the resources potential owned.

Sei ljum Raya village community involvement in the process of planning the Minapolitan area development through Participatory Planning. Participatory planning in Sei ljum Raya Village community demands to be more active thus, it can be treated as a government partner. The involvement of the community in the early stages of development carried out through participatory planning aims to formulate a program in accordance with community needs, evaluated and explored by the community. The thing that is often forgotten in a participatory planning is the quality of the community as an input to determine the outcome of planning conducted. Sei ljum Rayavillage still needs a boost where people want to be involved and become a determinant of the success and sustainability of a plan. In the field, the coordination role has not fully invited the groups' involvement outside the government in order to implement, collect and analyze the information that will be the basis of regional development policy. Regional development planning that is able to involve all existing stakeholders to participate is a participatory development plan. Lack of harmonious cooperation among the governments is a fundamental factor in achieving more realistic and more community-driven development policies. Based on the findings in the field, three actors in minapolitan area development are government, community and private sector who are very important in realizing the policy implementation.

The local organization capacity in honing the community's ability to cooperate, organizes individuals and groups within it, in order to mobilize the existing resources in solving problems with well-organized communities able to make their voices heard better and the needs fulfilled still require a companion and facilitator.

Supporting and Inhibiting Factors in Minapolitan Area Development based on participatory planning in improving the fishermen communities' welfare in Sei ljum Raya Village. The availability of natural resources is the capital of minapolitan areas development. The natural resources are in the form of water and land support the development of minapolitan areas. In increasing the public income, the development of the minapolitan area is a development concept to realize the independence of fishermen community with the effort to make leverage of the regional economy in order to increase the fishermen community 
income by realizing entrepreneur spirit in the community. The positive perception of the community due to the increase of income is a factor that is accepted by the community in minapolitan area development and the characteristics of the fisherman community of the Sei ljum Raya village, which is always adjacent to the river is a local wisdom that can support the fishery business run by the community for generations. The recent condition of the community seen from the development benefits through minapolitan areas development concept has been felt even though the cultivation system is done traditionally.

The existence of human resources is one of the most important things that is always used as a foundation for an area development. The main problem in development policy is based on the regional specificity (endogenous development) by using human resource potential. The low quality of human resources is caused by unqualified education.

Infrastructure is the main thing in an area development because it brings the influence in the success. In this case, Roads and docks are very important access because it is a trade mobilization of an area.

\section{CONCLUSION}

Based on the results of research and discussion focusing on the problem of this research, several things can be concluded as follows:

Seen from its demography aspect, Sei ljum Raya Village has various potentials. This village can be said unique with numerous deep coconut trees in the Minapolitan area as the inheritance of their ancestral land. The land utilization of coconut trees planting can be used for fish farming, which is a boon. This condition deserves appreciation and support from the aspects of cultivation techniques, processing management and marketing because it can overcome the economic problems when the famine season/ fishing season comes as it really depends on the weather factors. The Awareness of Sei ljum raya village community on the importance of excavating the potential of the area is still very low, so it needs to be improved, with the potential identification of a region can encourage its region development. The identification of potential yields other than capture fisheries is a potential sector to be developed, while the deep coconut plantation sector is the leading commodity. Therefore, it is obtain an integration of Fish Pond-Deep Coconut in order to support the development of Minapolitan area. This is in line with the local government support with the issuance of the Decree of the Regent No.188.45/326/ Huk-DKP/ 2015 on the location determination of Minapolitan Area Development activities in East Kotawaringin Regency. Through the regent's decree, program plans have been developed through the relevant SKPD as well as crosssectorial, so the minapolitan areas development can be accelerated through infrastructure development, public service system, raw material distribution network and production through various funding sources.

Regarding the planning process stages of Minapolitan area development in Sei ljum Raya Village, looking at the potential in Sei ljum Raya Village, the local government of East Kotawaringin Regency takes the initiative to decide minapolitan area development. The involvement of the community in the early stages of this minapolitan area development is not really seen because the policies characteristics are more top down as the leading sector Bappeda of Kotim Regency. Stages in the process of minapolitan area development have been done according to existing regulations, in which the first stage has been done in accordance with the master plan and restra as well as RPJDM of Kotim Regency. The forms and the quality of participation in the minapolitan areas development have not been felt by Sei ljum Raya village community because of their fishing and gardening activity in their daily life so that sometimes they are not or even rarely involved in various Minapolitan area development activities. But, in recent times, it has been held socialization which encourages Sei ljum Raya Village community involvement. The actors involved in Minapolitan area developmetn are the private sector and the community which are still less perceived in the Minapolitan area developmet. Therefore, synergy occurs less than expected. The regional commitment is indispensable in the Minapolitan area development in Sei ljum Raya Village. In terms of institutional village, Sei ljum Raya has had a forum that can help the fishermen 
community but it still requires assistance through socialization and training to find problems' solution that are still felt by Sei ljum Raya Village community.

Supporting factors in Minapolitan area development is needed to support the implementation of minapolitan area development. Those are natural resources availability, the increase of the fishermen community income, and the characteristics of the fishermen community of Sei ljum raya Village. Meanwhile, the inhibiting factors in East kotawaringin regency include: human resources and infrastructure.

\section{SUGGESTIONS}

Based on the conclusions of the research results that have been stated above, the researchers provide suggestions for improvements in the future minapolitan areas development, as follows:

Planning that can be an alternative to refine and overcome minapolitan areas development is to integrate the potential and natural resources, aligning all development plans by utilizing the local potential. According to the researchers, one of the efforts for the minapolitan area development that can be driven from the integration of deep coconut-fishery ponds through the support of the local government of East Kotawaringin Regency.

Planning policy is the basic guidelines of regional development process. The importance of various stakeholders' involvement is indispensable. A forum planning involves not only competent stakeholders but also communities and actors involved in the hope of answering all the problems because the planning is still sectorial. According to the researcher, community involvement in the area development planning is crucial. The lack of coordination and division of roles in planning resulted in a lack of synergy between the stakeholders. The basis of Minapolitan area development in Sei ljum Raya Village is the potential of Natural Resources owned. In this case, Minapolitan area development still needs guidance in terms of institutional continuity with the synergy of various parties, especially professionals.

Utilizing the supporting factors in minapolitan area development of Sei ljum Raya Village optimally.

\section{REFERENCES}

1. Abe, Alexander.2005 Perencanaan Daerah Partisipatif.Pembaruan Yogyakarta.

2. Badan Pusat Statistik.2012. Kotawaringin Timur Dalam Angka Tahun 2016 BPS.Kabupaten Trenggalek.

3. Conyers, Dianna, dan Piter Hills, 1992. An Introduction to social planning in the Third World, New York. John Wiley dan Sons

4. Faludi, Andreas, (1973) Planning Theory, United Kingdom: Pergamon Press

5. Kuncoro, Mudrajad, 2004. Otonomi dan Pembanguan Daerah, Reformasi Perencanaan, Strategi dan Peluang.Jakarta Erlangga.

6. Kementrian Kelautan dan Perikanan.2011.Peraturan Menteri Kelautan dan Perikanan RI Nomor PER 18/MEN/2012 tentang Pedoman Penyusunan Rencana Induk Pengembangan Kawasan Minapolitan, Jakarta.

7. Matthew B. Miles, A. Michael Huberman, Johnny Saldana. Qualitative Data Analysis A Methods Sourcebook, edisi 3 Google Buku, diakes pada tanggal 20 Desember 2014

8. Muluk,Khairul. 2007. Menggugat Partisipasi Publik dalam Pemerintahan Daerah,Sebuah kajian Administrasi Publik dengan Pendekatan Berpikir Sistem.Banyumedia Publishing

9. Muhammad,Sabri. 2012. Model Kemitraan Penanggulangan Kemiskinan dan Kesepakatan Lokal.Universitas Brawijaya Press (UB Press)

10. Pemerintah Kabupaten Kotawaringin Timur, 2015.Surat Keputusan Bupati Kabupaten Kotawaringin Timur No.188.45/326/Huk-DKP/2015 tentang Penetapan Lokasi Kegiatan Pengembangan Kawasan Minapolitan di Kabupaten Kotawaringin Timur

11. 2015. Profil Desa /Kelurahan Mentaya Hilir Selatan kabupaten Kotawaringin Timur 
12. 2016.Laporan Tahunan Dinas Kelautan dan Perikanan Kabupaten Kotawaringin Timur tahun 2016.Kotawaringin Timur

13. Primyastanto,Mimit. 2011. Minapolitan Suatu Pendekatan Ekonomi, Sosial, Lingkungan, dan Agama.Universitas Brawijaya Press (UB Press).

14. Riyadi dan Deddy S. Bratakusumah, 2006, Perencanaan Perencanaan Pembangunan Daerah: Strategi mengali potensi dalam mewujudkan Otonomi Daerah, Jakarta, PT Gramedia Pustaka Utama.

15. Sjaprizal, 2014, Perencanaan Pembangunan Daerah dalam Era Otonomi, Devisi Buku Perguruan Tinggi, Penerbit PT. Raja Grafindo, Jakarta

16. Soetomo, 2013, Pemberdayaan Masyarakat mungkinkah muncul anti tesisnya, pustaka Pelajar, Celeban Timur UH III /548 Yogyakarta.

17. Sugiyono, 2011.Metode penelitian Kualitatif dan R\&D. Alfabet, Bandung.

18. Totok Mardikanto,dkk. 2015. Pemberdayaan Masyarakat dalam Perpektif kebijakan Publik.Alfabeta.Bandung

19. Tjokroamidjojo Bintoro, 1974, Pengantar Administrasi Pembangunan, Cetakan Pertama, Penerbit LP3S, Jakarta.

20. Todaro, Michael P.2004.Pembangunan Ekonomi di Dunia Ketiga Buku 1. Diterjemahkan oleh Harris Munandar.Erlangga Jakarta. 